\title{
ВИДИ ТА ОСОБЛИВОСТІ ФОРМУВАННЯ СОЦІАЛЬНО-ЕКОНОМІЧНИХ РЕЗУЛЬТАТІВ РОЗМІЩЕННЯ ВЕЛОТРЕНАЖЕРІВ 3 ФУНКЦІЄЮ ПІДЗАРЯДКИ ЗОВНІШНІХ ПРИСТРОЇВ НА ТЕРИТОРІЇ ВИЩИХ НАВЧАЛЬНИХ ЗАКЛАДІВ
}

Встановлено види та визначено особливості формування соціально-економічних результатів розміщення велотренажерів 3 функцією підзарядки зовнішніх пристроїв на території вищих навчальних закладів (ВН3). Виявлено, що основними видами таких результатів є: покращення стану здоров'я студентів, отримання студентами певної матеріальної вигоди, підвищення рівня привабливості ВНЗ серед потенційних абітурієнтів, покращення результатів навчального процесу, отримання ВНЗ певного фінансового зиску, економія енергії, покращення екології, поліпшення стану з утилізації зношених велосипедів. Встановлено, що кожен вид соціально-економічних результатів розміщення велотренажерів з функцією підзарядки зовнішніх пристроїв на території ВНЗ характеризується певним способом його формування, що, водночас, зумовлює потребу у розробленні методологічного підходу до окремого оцінювання кожного з цих видів результатів. Виявлено існування альтернативних варіантів реалізації проектів розташування на території ВНЗ велотренажерів. До цих варіантів віднесено: придбання нового велотренажеру, придбання велотренажеру, переробленого зі зношеного велосипеду, самостійне виготовлення велотренажеру шляхом перероблення зношеного велосипеду. Запропоновано критерій вибору найкращої моделі велотренажера. Цим критерієм є мінімум середньорічних сумарних витрат на його придбання та експлуатацію. З'ясовано, що внаслідок порівняння двох альтернатив, а саме - придбання нового велотренажеру та велотренажеру, який виготовлено зі зношеного велосипеду, другий варіант є кращим, оскільки значення критеріального показника за ним є меншим. Проте, якщо порівнювати варіанти придбання велотренажеру та його виготовлення власними силами зі зношеного велосипеду, то за другою альтернативою величина критерію є меншою. Тому проект організації власного виробництва велотренажерів зі зношених велосипедів за наявності у ВНЗ відповідної матеріально-технічної бази є економічно доцільним. На підставі проведеного опитування студентів львівських ВНЗ виявлено їх зацікавленість у розміщенні велотренажерів з функцією підзарядки зовнішніх пристроїв на території цих вищих навчальних закладів. Виділено ризики, пов'язані із таким розміщенням.

Ключові слова: студент; стан здоров'я, тренажер; тренування; економія енергії; інвестиційні витрати.

\section{Вступ}

На сьогодні багатьом молодим особам, особливо працівникам сфери IT-галузі, притаманна недостатня фізична активність, що негативно позначається на стані ïх здоров'я. Зокрема, ця проблема характерна і для студентів вищих навчальних закладів (ВНЗ). Одним зі шляхів її вирішення є розміщення на території цих закладів різноманітних тренажерів, за допомогою яких студенти могли б, принаймні частково, задовольнити наявну у них потребу у фізичній активності. Разом 3 тим, таке розміщення потребує попереднього оцінювання його соціально-економічних результатів. Це пов'язано із тим, що розташування тренажерів на території
ВНЗ зумовлює як додаткові ризики, так і супутні вигоди, які можуть отримувати не тільки студенти, але й самі ВНЗ та суспільство загалом. Зокрема, багато результатів може зумовити розташування у ВНЗ таких різновидів спортивних тренажерів, як велотренажери 3 функцією підзарядки зовнішніх пристроїв. Тому важливо виділити найвагоміші такі результати та запропонувати методологічні підходи до їх оцінювання, що і є актуальним дослідженням. Його б результати могли сприяти розповсюдженню практики розташування у ВНЗ України та інших країн цих видів велотренажерів.

Об'єкт дослідження - формування соціально-економічних результатів розміщення велотренажерів 3 функцією підзарядки зовнішніх пристроїв.

\section{Інформація про авторів:}

Вовк Олена Борисівна, канд. техн. наук, доцент, кафедра систем штучного інтелекту. Email: olena.b.vovk@lpnu.ua; https://orcid.org/0000-0001-5523-0901

Ємельянов Олександр Юрійович, д-р екон. наук, доцент, кафедра економіки підприємства та інвестицій. Email: oleksandr.y.yemelianov@lpnu.ua; https://orcid.org/0000-0002-1743-1646

Симак Анастасія Валеріївна, канд. екон. наук, доцент, кафедра економіки підприємства та інвестицій. Email: anastasiia.v.symak@Ipnu.ua; https://orcid.org/0000-0001-6371-2206

Лесик Лілія Іванівна, канд. екон. наук, доцент, кафедра економіки підприємства та інвестицій. Email: lilia.lesyk@gmail.com; https://orcid.org/0000-0003-1324-9027

Цитування за ДСТУ: Вовк О. Б., Ємельянов О. Ю., Симак А. В., Лесик Л. І. Види та особливості формування соціальноекономічних результатів розміщення велотренажерів з функцією підзарядки зовнішніх пристроїв на території вищих навчальних закладів. Науковий вісник НЛтУ України. 2020, т. 30, № 5. С. 94-99.

Citation APA: Vovk, O. B., Yemelyanov, O. Yu., Symak, A. V., \& Lesyk, L. I. (2020). Some types and features of formation of social and economic results of placement of exercise bikes with function of external devices recharging in the territory of higher education institutions. Scientific Bulletin of UNFU, 30(5), 94-99. https://doi.org/10.36930/40300516 
Предмет дослідження - методи і засоби визначення соціально-економічних результатів розміщення велотренажерів з функцією підзарядки зовнішніх пристроїв на території ВНЗ та встановлення особливостей їх формування.

Мета роботи - встановлення видів й визначення особливостей формування соціально-економічних результатів розміщення велотренажерів 3 функцією підзарядки зовнішніх пристроїв на території вищих навчальних закладів 3 урахуванням способу набуття цих тренажерів.

Для досягнення зазначеної мети визначено такі основні завдання дослідження: згрупувати види соціально-економічних результатів розміщення велотренажерів 3 функцією підзарядки зовнішніх пристроїв на території ВНЗ; розробити методологічні засади вибору найкращого варіанта набуття та розміщення велотренажерів; визначити особливості формування соціальноекономічних результатів такого розміщення.

Наукова новизна отриманих результатів дослідження - вперше розроблено методику, яка дає змогу здійснити групування соціально-економічних результатів від реалізації проекту розташування велотренажерів 3 функцією підзарядки зовнішніх пристроїв на території ВНЗ за суб'єктами, що отримують відповідні результати; вдосконалено методологічні засади вибору найкращого варіанта набуття та розміщення велотренажерів завдяки використанню критерію мінімуму середньорічних сумарних витрат; розвинуто теоретичні особливості формування соціально-економічних результатів розміщення велотренажерів на території ВНЗ шляхом деталізованого виділення джерел такого формування.

Практична значущість результатів дослідження можливість їх застосування під час обгрунтування варіантів прийняття рішень про розташування велотренажерів з функцією підзарядки зовнішніх пристроїв на території ВНЗ та про вибір найкращого варіанта придбання таких тренажерів.

Аналіз останніх досліджень та публікацій. Оцінювання соціально-економічних результатів розміщення велотренажерів на території ВНЗ значною мірою пов'язано із впливом цих тренажерів на стан здоров'я студентів, що будуть займатися на них. Як зазначено у дослідженні Т. Кириченко, використання тренажерів може відігравати істотну роль у тренуванні студентів ВН3, забезпечуючи вплив на їх опорно-руховий апарат, серцево-судинну, дихальну та нервову системи [2]. Подібної думки дотримується і Т. М. Редько, що наголошує на позитивному значенні використання тренажерів у фізичному вихованні студентів педагогічних ВН3 [6]. Однак, як зазначають Є. І. Комаревич та О. Є. Комаревич, використання велотренажерів студентами для розвитку їх фізичних якостей потребує дотримання певних методичних рекомендацій з урахуванням стану здоров'я та інших параметрів осіб, що користуватимуться цими тренажерами [1]. Також варто погодитися із думкою Л. І. Міщик та М. О. Гладиш про важливу роль, які відіграють тренажери (зокрема - і велотренажери) у забезпеченні соціалізації студентів з особливими потребами [4]. При цьому, однак, варто враховувати можливу потребу в регулюванні та координації процесу використання студентами велотренажерів, що розміщені на території ВНЗ. Зокрема, на погляд В. Жамардія, у цьому контексті важливу роль може відігравати тренер-викла- дач [12]. Отже, розміщення велотренажерів на території ВН3 можна розглядати як важливий засіб посилення мотивації студентів до систематичної рухової активності оздоровчого спрямування, на необхідності чого наголошують Г. А. Єдинак зі співавторами [9]. Окрім цього, таке застосування велотренажерів доцільно досліджувати й у системі ціннісних пріоритетів студентів, яку розглядав, зокрема, Т. Г Кириченко [3]. При цьому потрібно враховувати різноманітні організаційні проблеми, що постають у процесі навчально-тренувальної роботи зі студентами, які дослідив Л. М. Рядинський [7].

Отже, застосування студентами велотренажерів доцільно розглядати, насамперед, у контексті впровадження у ВНЗ здоров'язбережувальних технологій, які досліджували Є. Л. Михалюк та С. М. Малахова [5]. При цьому варто враховувати й інші соціально-економічні наслідки розміщення велотренажерів на території ВН3, зокрема, економічний ефект від такого розміщення, про який згадують О. Б. Вовк зі співавторами [8]. Якщо ж розглядати різновид велотренажеру, який дає змогу провадити підзарядку зовнішніх пристроїв, то у цьому разі постає потреба і в оцінюванні можливостей енергозбереження та використання відновних джерел енергії, що, як показали О. Ю. Смельянов зі співавторами, на сьогодні є надзвичайно актуально для української економіки $[10,11]$.

\section{Результати дослідження та їх обговорення}

Розташування на території ВНЗ велотренажерів 3 функцією підзарядки зовнішніх пристроїв потрібно розглядати як певний інвестиційний проект, що потребує понесення деякої величини витрат та може забезпечувати отримання певних результатів від своєї реалізації. При цьому для будь-якого проекту можливо виділити інвестора, виконавця, а також тих, хто відповідає за ресурсне забезпечення реалізації проекту.

Стосовно проекту розташування на території ВН3 велотренажерів $з$ функцією підзарядки зовнішніх пристроїв, то інвестором у цьому разі виступає керівництво закладу освіти, а виконавцем - підрозділ (підрозділи) закладу, який відповідає за матеріальне забезпечення діяльності ВНЗ. Щодо ресурсного забезпечення розглядуваного проекту, то воно містить як фінансове, так i матеріальне забезпечення. Зокрема, таке забезпечення може відбуватися власними силами ВН3, а також із залученням сторонніх осіб.

Окрім цього, як і будь-який інший масштабний інвестиційний проект, проект розташування на території ВНЗ велотренажерів повинен спиратися на певну його бізнес-модель. Узагальнювальний вигляд цієї моделі для розглядуваного проекту подано на рисунку. Серед іншого, ця модель враховує чинник ризику та виокремлює економічні та соціальні наслідки розташування на території ВНЗ велотренажерів. При цьому потрібно враховувати такі особливості цього проекту: 1) наявність значної кількості соціально-економічних наслідків його реалізації; 2) існування альтернативних варіантів його реалізації; 3) масовий характер використання велотренажерів у разі їх розміщення на території закладу освіти.

Стосовно першої особливості розглядуваного проекту, то соціально-економічні наслідки розміщення велотренажерів $з$ функцією підзарядки зовнішніх пристроїв на території ВНЗ доцільно поділити за суб'єктами, що 
отримують відповідні соціально-економічні результати. До основних таких результатів у розрізі їх реципієнтів доцільно віднести:

1) для студентів, які користуватимуться велотренажерами:

- покращення стану здоров'я завдяки систематичній руховій активності, здоровому способу життя, зменшенню схильності до шкідливих звичок тощо;

- отримання певної матеріальної вигоди, зокрема, внаслідок часткової заміни тієї рухової активності, забезпечення якої потребує оплату з боку студентів (послуги тренажерних залів тощо);

2) для ВНЗ:

- підвищення рівня привабливості ВНЗ серед потенційних абітурієнтів;

- покращення результатів навчального процесу завдяки поліпшенню стану здоров'я студентів;

- отримання певного фінансового зиску у разі, якщо виготовлення велотренажерів здійснюватиметься у виробничих підрозділах ВНЗ з подальшим продажем частини цих тренажерів на сторону;

3) для суспільства загалом:

- економія енергії;

• покращення екології завдяки виробітку чистої енергії;

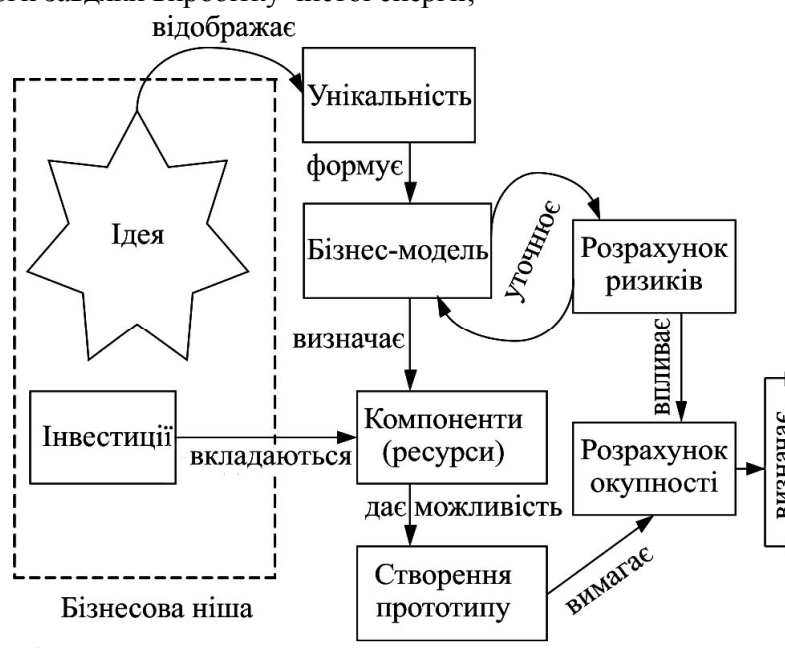

- покращення стану з утилізації зношених велосипедів за умови, що їх будуть переробляти у велотренажери.

Треба зазначити, що кількісне оцінювання перелічених соціально-економічних наслідків розташування на території ВНЗ велотренажерів з функцією підзарядки зовнішніх пристроїв стикається з певними труднощами. Ці труднощі зумовлені, зокрема, необхідністю розгляду різних варіантів реалізації проекту такого розташування. Серед цих варіантів: залучення нових велотренажерів або тренажерів, перероблених зі зношених велосипедів; придбання велотренажерів або їх самостійне виготовлення (якщо відповідний заклад освіти має підсобне виробництво, яке здатне провадити таке виготовлення); розташування велотренажерів тільки у приміщеннях ВНЗ або також і на вулиці тощо.

Стосовно масового характеру використання велотренажерів у разі їх розміщення на території закладів освіти, то врахування цього чинника можливо здійснити, зокрема, шляхом опитування студентів. Результати такого опитування, виконаного серед чотирьохсот студентів п'яти львівських ВНЗ, наведено у табл. 1.

Рисунок. Узагальнена бізнес-модель проекту

Табл. 1. Результати опитування студентів ВНЗ Львова щодо їх ставлення до розміщення на території цих закладів вищої освіти велотренажерів 3 функцією підзарядки зовнішніх пристроїв

Поставлені запитання та варіанти відповідей на них

Економічну вигоду (економічну доцільність)

Соціальну вигоду (соціальний ефект)

\begin{tabular}{|c|c|c|}
\hline \multirow[t]{2}{*}{ Поставлені запитання та варіанти відповідей на них } & \multicolumn{2}{|c|}{$\begin{array}{l}\text { Респонденти, що надали } \\
\text { позитивні відповіді: }\end{array}$} \\
\hline & кількість, осіб & частка, \% \\
\hline \multicolumn{3}{|c|}{$\begin{array}{l}\text { 1. Як Ви ставитися до розміщення на території Вашого навчального закладу велотренажерів з фун- } \\
\text { кцією підзарядки зовнішніх пристроїв? }\end{array}$} \\
\hline 1.1. Позитивно & 323 & 80,75 \\
\hline 1.2. Нейтрально & 26 & 6,50 \\
\hline 1.3. Негативно & 51 & 12,75 \\
\hline \multicolumn{3}{|c|}{ 2. Чи будете Ви користуватися такими тренажерами у разі їх розташування на території Вашого ВНЗ? } \\
\hline 2.1. Буду постійно & 241 & 60,25 \\
\hline 2.2. Буду періодично & 72 & 18,00 \\
\hline 2.3. Не буду взагалі & 87 & 21,75 \\
\hline \multicolumn{3}{|c|}{$\begin{array}{l}\text { 3. Якими, на Вашу думку, є потенційні зиски, що можуть бути отримані Вами від розміщення на те- } \\
\text { риторії Вашого навчального закладу велотренажерів з функцією підзарядки зовнішніх пристроїв?* }\end{array}$} \\
\hline 3.1. Покращення стану мого здоров'я & 309 & 77,25 \\
\hline 3.2. Отримання певних фінансових зисків & 44 & 11,00 \\
\hline 3.3. Жодних вигод не бачу & 58 & 14,50 \\
\hline \multicolumn{3}{|c|}{$\begin{array}{l}\text { 4. Якими, на Вашу думку, є потенційні ризики, що пов'язані із розміщенням на території Вашого } \\
\text { навчального закладу велотренажерів з функцією підзарядки зовнішніх пристроїв?* }\end{array}$} \\
\hline 4.1. Ризик псування тренажерів у процесі їх експлуатації & 178 & 44,50 \\
\hline 4.2. Ризик псування тренажерів внаслідок свідомого їх нищення & 63 & 15,75 \\
\hline 4.3. Ризик нестачі тренажерів для задоволення попиту в них усіх охочих & 229 & 57,25 \\
\hline 4.4. Інші види ризиків & 15 & 3,75 \\
\hline 4.5. Ризиків не вбачаю & 47 & 11,75 \\
\hline
\end{tabular}

Примітка: * на ці запитання респонденти мали право надавати одночасно декілька відповідей 
Як випливає 3 даних, наведених у табл. 1, більше $80 \%$ опитаних студентів схвально віднеслися до ідеї розташування велотренажерів на території ВНЗ. Окрім цього, понад $65 \%$ респондентів висловили бажання брати участь у тренуваннях на цих тренажерах. Отже, розташування на території ВНЗ велотренажерів з функцією підзарядки зовнішніх пристроїв покращує імідж навчальних закладів і може виступати однією з їхніх переваг у виборі абітурієнтами майбутніх місць здобуття освіти.

Разом $з$ тим, більшість студентів вказала на те, що очікує від користування велотренажерами переважно покращення стану свого здоров'я, тоді, як можливість отримання фінансового зиску від такого користування більшістю студентів не передбачається. Важливо також зазначити, що серед найбільших ризиків, пов'язаних із використанням велотренажерів, розташованих на території ВН3, опитані студенти назвали ризик нестачі тренажерів для задоволення попиту в них усіх охочих. Очевидно, що запобігання цьому ризику потребує як забезпечення наявності достатньої кількості велотренажерів, так і регламентації граничної тривалості одного сеансу їх використання.

Стосовно вибору найкращих варіантів реалізації проекту розміщення велотренажерів 3 функцією підзарядки зовнішніх пристроїв на території ВНЗ, то видається доцільним, передусім, розглянути такі з цих варіантів:

1. Придбання нового велотренажеру.

2. Придбання велотренажеру, переробленого із зношеного велосипеду. У цьому разі величина інвестиційних витрат у реалізацію проекту буде меншою порівняно із попереднім варіантом його здійснення, однак, більшими будуть експлуатаційні витрати (зокрема, витрати на ремонт), а тривалість експлуатації, навпаки, меншою.

3. Самостійне виготовлення велотренажеру шляхом перероблення зношеного велосипеду. Розгляд цього варіанта є доцільним, якщо у закладі освіти існує виробничий підрозділ, який у принципі може здійснювати таке виготовлення (можливо при цьому буде потрібним понесення певних капітальних видатків на те, щоб цей підрозділ міг виконувати процеси перероблення зношених велосипедів у велотренажери).

Для того, щоб обрати найкращий варіант 3 перших двох, доцільно скористатися таким критерієм:

$$
Z \cdot T=I+\sum_{t=1}^{T} C_{t} \rightarrow \min ,
$$

де: $Z$ - критерій вибору найкращої моделі велотренажера (середньорічні сумарні витрати на його придбання та експлуатацію), грошових одиниць; $I$ - інвестиційні (одноразові) витрати на придбання певної моделі велотренажера, грошових одиниць; $T$ - термін корисної експлуатації певної моделі велотренажера, років; $C_{t}-$ річні експлуатаційні витрати за певною моделлю велотренажера у $t$-му році, грошових одиниць.
Критерій (1) можна певною мірою модифікувати та зробити точнішим, якщо ввести у нього процедуру дисконтування експлуатаційних витрат. Тоді цей критерій набуде такого вигляду:

$$
Z^{\prime} \cdot T=I+\sum_{t=1}^{T} \frac{C_{t}}{(1+r)^{t}} \rightarrow \min ,
$$

де $r$ - дисконтна ставка, частки одиниці.

Необхідно відзначити, що критерії (1) та (2) можуть бути застосовуваними і в разі розгляду варіанта виготовлення велотренажеру власними силами виробничого підрозділу ВНЗ. Проте, у цьому випадку показник $I$ потребує попереднього розрахунку за такою формулою:

$$
I^{\prime}=C_{p}+\frac{I_{c} \cdot r}{n}
$$

де: $C_{p}$ - витрати на виробництво власними силами ВНЗ одного велотренажеру зі зношеного велосипеду, грошових одиниць; $I_{c}-$ інвестиційні витрати у створення у ВНЗ власного виробництва велотренажерів; $n$ - обсяг виготовлення велотренажерів за рік, одиниць.

Варто також враховувати той факт, що значення наведених вище критеріальних показників будуть відрізнятися залежно від того, де розміщуватиметься велотренажер - у приміщенні або на вулиці. В останньому випадку більшою буде величина експлуатаційних витpat.

Результати виконаних обчислень значень критеріального показника (2) для різних випадків набуття та розміщення велотренажеру на території ВНЗ наведено у табл. 2. Як свідчать дані цієї таблиці, якщо розглядати придбання нового велотренажеру та велотренажеру, який виготовлено зі зношеного велосипеду, то другий варіант є кращим, оскільки значення показника (2) за ним $\epsilon$ меншими. При цьому рівень інвестиційних витрат у придбання велотренажерів, перероблених зі зношених велосипедів, є приблизно у вісім разів меншим за цей рівень у разі придбання нових велотренажерів. Якщо ж порівнювати варіанти придбання велотренажеру та його виготовлення власними силами зі зношеного велосипеду, то за другою альтернативою величина критерію (2) є меншою. Отже, проект організації власного виробництва велотренажерів зі зношених велосипедів за наявності у ВНЗ відповідної матеріально-технічної бази є економічно доцільним.

Характеристику соціально-економічних результатів розміщення велотренажерів з функцією підзарядки зовнішніх пристроїв на території ВНЗ узагальнено у табл. 3. Як випливає з даних цієї таблиці, кожен вид соціально-економічних результатів розміщення велотренажерів $з$ функцією підзарядки зовнішніх пристроїв на території ВНЗ характеризується певним способом його формування, що, водночас, зумовлює потребу у розробленні методологічного підходу до оцінювання кожного 3 цих видів результатів.

\begin{tabular}{|c|c|c|c|}
\hline \multirow{2}{*}{$\begin{array}{c}\text { Способи розміщення } \\
\text { велотренажеру }\end{array}$} & \multicolumn{3}{|c|}{ Способи набуття велотренажеру } \\
\hline & $\begin{array}{l}\text { Придбання нового } \\
\text { велотренажеру }\end{array}$ & $\begin{array}{c}\text { Придбання велотренажеру, виробле- } \\
\text { ного зі зношеного велосипеду }\end{array}$ & $\begin{array}{c}\text { Виготовлення велотренажеру } \\
\text { зі зношеного велосипеду }\end{array}$ \\
\hline Розміщення у приміщенні & 1607 & 1058 & 914 \\
\hline Розміщення на вулиці & 1914 & 1701 & 1483 \\
\hline
\end{tabular}

Табл. 2. Значення критерію (2) для різних варіантів набуття та розміщення велотренажеру на території ВНЗ, тис. грн у розрахунку на один велотренажер 
Табл. 3. Види соціально-економічних результатів розміщення велотренажерів з функцісю підзарядки зовнішніх пристроїв на території ВНЗ, особливості формування цих результатів та підходи до їх оцінювання

\begin{tabular}{|c|c|c|}
\hline $\begin{array}{c}\text { Вид соціально-економічних } \\
\text { результатів } \\
\end{array}$ & $\begin{array}{c}\text { Особливості формування соціально-економіч- } \\
\text { них результатів } \\
\end{array}$ & $\begin{array}{l}\text { Методологічні підходи до оцінювання } \\
\text { соціально-економічних результатів } \\
\end{array}$ \\
\hline $\begin{array}{l}\text { Покращення стану здоров'я } \\
\text { студентів }\end{array}$ & $\begin{array}{l}\text { Завдяки систематичній руховій активності, } \\
\text { здоровому способу життя, зменшенню схиль- } \\
\text { ності до шкідливих звичок тощо }\end{array}$ & $\begin{array}{l}\text { Оцінювання впливу занять на велотренажерах } \\
\text { на покращення стану здоров'я студентів }\end{array}$ \\
\hline $\begin{array}{l}\text { Отримання студентами певної } \\
\text { матеріальної вигоди }\end{array}$ & $\begin{array}{l}\text { Зокрема, внаслідок часткової заміни тієї рухо- } \\
\text { вої активності, забезпечення якої потребує оп- } \\
\text { лати з боку студентів (послуги тренажерних } \\
\text { залів тощо) }\end{array}$ & $\begin{array}{l}\text { Оцінювання впливу занять на велотренажерах } \\
\text { на зниження видатків студентів на відвідуван- } \\
\text { ня ними тренажерних залів }\end{array}$ \\
\hline $\begin{array}{l}\text { Підвищення рівня привабли- } \\
\text { вості ВНЗ серед потенційних } \\
\text { абітурієнтів }\end{array}$ & $\begin{array}{l}\text { Завдяки соціально-економічному зиску, який } \\
\text { отримуватимуть студенти від користування } \\
\text { велотренажерами }\end{array}$ & $\begin{array}{l}\text { Оцінювання впливу розміщення велотренаже- } \\
\text { рів на території ВНЗ на вибір абітурієнтами } \\
\text { цих закладів }\end{array}$ \\
\hline $\begin{array}{l}\text { Покращення результатів нав- } \\
\text { чального процесу }\end{array}$ & Завдяки поліпшенню стану здоров'я студентів & $\begin{array}{l}\text { Оцінювання впливу поліпшення стану здоров'я } \\
\text { студентів на покращення результатів навчаль- } \\
\text { ного процесу }\end{array}$ \\
\hline $\begin{array}{l}\text { Отримання ВНЗ певного фі- } \\
\text { нансового зиску }\end{array}$ & $\begin{array}{l}\text { У разі, якщо виготовлення велотренажерів } \\
\text { здійснюватиметься у виробничих підрозділах } \\
\text { ВНЗ з подальшим продажем частини цих тре- } \\
\text { нажерів на сторону }\end{array}$ & $\begin{array}{l}\text { Оцінювання фінансових результатів від прода- } \\
\text { жу велотренажерів }\end{array}$ \\
\hline Економія енергії & $\begin{array}{l}\text { Завдяки виготовленню електроенергії велотре- } \\
\text { нажерами }\end{array}$ & $\begin{array}{l}\text { Оцінювання величини виробітку електроенер- } \\
\text { гії завдяки використанню велотренажерів }\end{array}$ \\
\hline Покращення екології & Завдяки виробітку чистої енергії & $\begin{array}{l}\text { Оцінювання зменшення викидів двоокису вуг- } \\
\text { лецю завдяки використанню велотренажерів }\end{array}$ \\
\hline $\begin{array}{l}\text { Покращення стану з утилізації } \\
\text { зношених велосипедів }\end{array}$ & $\begin{array}{l}\text { У разі, якщо буде відбуватися перероблення } \\
\text { зношених велосипедів у велотренажери }\end{array}$ & $\begin{array}{l}\text { Оцінювання скорочення величини витрат на } \\
\text { утилізацію зношених велосипедів завдяки їх } \\
\text { переробленню у велотренажери }\end{array}$ \\
\hline
\end{tabular}

\section{Висновки}

Основними видами соціально-економічних результатів розміщення велотренажерів з функцією підзарядки зовнішніх пристроїв на території ВНЗ є: покращення стану здоров'я студентів, отримання студентами певної матеріальної вигоди, підвищення рівня привабливості ВНЗ серед потенційних абітурієнтів, покращення результатів навчального процесу, отримання ВНЗ певного фінансового зиску, економія енергії, поліпшення екології, покращення стану з утилізації зношених велосипедів. При цьому існують альтернативні варіанти реалізації проектів розташування на території ВНЗ велотренажерів. До цих варіантів доцільно віднести: придбання нового велотренажеру, придбання велотренажеру, переробленого зі зношеного велосипеду, самостійне виготовлення велотренажеру шляхом перероблення зношеного велосипеду. Критерієм вибору найкращого з цих варіантів повинен виступати мінімум середньорічних сумарних витрат на придбання та експлуатацію велотренажеру. При цьому за певних умов доцільно реалізовувати проект організації власного виробництва ВН3 велотренажерів зі зношених велосипедів. Подальші дослідження потребують визначення достатньо повного переліку цих умов.

\section{References}

1. Komarevych, Ye. I., \& Komarevych, O. Ye. (2013). Metodychni rekomendatsii z vykorystannia trenazheriv ta prystosuvan studentamy dlia rozvytku fizychnykh yakostei. Rivne: NUVHP, 32 p. [In Ukrainian].

2. Kyrychenko, T. H. (2017). Trenazhery v systemi sylovoho trenuvannia studentiv VNZ. Sportyvnyi visnyk Prydniprovia, 1, 156159. [In Ukrainian].

3. Kyrychenko, T. H. (2019). Zdorovia v systemi tsinnisnykh priorytetiv studentiv pedahohichnoho zakladu vyshchoi osvity. (Series: Fizychne vykhovannia, sport i zdorovia liudyny). Visnyk Kamianets-Podilskoho natsionalnoho universytetu imeni Ivana Ohiienka, 12, 22-27. [In Ukrainian].
4. Mishchyk, L. I., \& Hladysh, M. O. (2008). Sotsialno-pedahohichna diialnist VNZ yak umova adaptatsii studentiv z osoblyvymy potrebamy u sotsializatsii. (Series: Pedahohichni nauky). Visnyk Cherkaskoho universytetu, 122, 94-98. [In Ukrainian].

5. Mykhaliuk, Ye. L., \& Malakhova, S. M. (2015). Vykorystannia zdoroviazberezhuvalnykh tekhnolohii na suchasnomu etapi. Fizychna kultura, sport ta zdorovia. Proceedings of the V International Conference, 221-223. Retrieved from: http://journals.uran.ua/ksapc conference/article/viewFile/57820/54060

6. Redko, T. M. (2015). Vykorystannia trenazheriv u fizychnomu vykhovanni studentiv pedahohichnykh VNZ. (Series: 15: Naukovo-pedahohichniproblemy fizychnoi kultury (fizychna kultura i sport). Naukovyi chasopys Natsionalnoho pedahohichnoho universytetu imeni, M. P. Drahomanova, 3(2), 289-292. [In Ukrainian].

7. Riadynskyi, L. M. (2004). Deiaki problemy fizychnoi pidhotovlenosti, fizychnoho rozvytku y orhanizatsii uchbovo-trenuvalnoi roboty zi studentamy. Pedahohika, psykholohiia ta medyko-biolohichni problemy fizychnoho vykhovannia i sportu, 23, 52-56.

8. Vovk, O. B., Symak, A. V., \& Lesyk, L. I. (2020). Otsiniuvannia sotsialno-ekonomichnykh naslidkiv roztashuvannia na terytorii VNZ vlotrenazheriv z funktsiiei pidzariadky zovnishnikh prystroiv. Zbirnyk naukovykh prats $\Lambda \mathrm{OHO} \Sigma$, Oxford, United Kingdom, July 24, 2020, 45-47. https://doi.org/10.36074/24.07.2020.v2.14

9. Yedynak, H. A., Mytskan, B. M., \& Zavatska, L. (2012). Stan ta deiaki teoretychni aspekty posylennia motyvatsii studentiv do systematychnoi rukhovoi aktyvnosti ozdorovchoho spriamuvannia. (Series: Fizychna kultura). Visnyk Prykarpatskoho universyte$t u, 16,44-50$. [In Ukrainian].

10. Yemelyanov, O., Symak, A., Petrushka, T., Lesyk, R., \& Lesyk, L. (2018). Evaluation of adaptability of Ukrainian economy to changes in prices for energy carriers and to energy market risks. Energies, 11(12), 3529. https://doi.org/10.3390/en11123529

11. Yemelyanov, O., Symak, A., Petrushka, T., Zahoretska, O., Kusiy, M., Lesyk, R., \& Lesyk, L. (2019). Changes in Energy Consumption, Economic Growth and Aspirations for Energy Independence: Sectoral Analysis of Uses of Natural Gas in Ukrainian Economy. $\quad$ Energies, $\quad 12(24), \quad 4724$. https://oi.org/10.3390/en12244724

12. Zhamardii, V. (2016). Rol trenera-vykladacha $\mathrm{v}$ provedenni navchalnykh zaniat $\mathrm{z}$ fizychnoho vykhovannia studentiv iz zastosuvanniam fitnes-tekhnolohii. (Series: Pedahohichni nauky). Vytoky pedahohichnoi maisternosti, 17, 84-89. [In Ukrainian]. 


\section{SOME TYPES AND FEATURES OF FORMATION OF SOCIAL AND ECONOMIC RESULTS OF PLACEMENT OF EXERCISE BIKES WITH FUNCTION OF EXTERNAL DEVICES RECHARGING IN THE TERRITORY OF HIGHER EDUCATION INSTITUTIONS}

Placement of exercise bikes with the function of recharging external devices on the territory of higher education institutions can propose a number of different positive socio-economic consequences. In this regard, the purpose of this work was to establish the types and features of the formation of socio-economic results of the placement of exercise bikes with the function of external devices recharging in the university area. The study was conducted using the method of expert survey and technical and economic calculations. It is established that the socio-economic consequences of placing exercise bikes with the function of recharging external devices in the territory of the university are diverse and can be divided into the appropriate socio-economic effect. In particular, the following consequences are available for students: improved health through regular physical activity, a healthy lifestyle, reduced susceptibility to bad habits, etc.; obtaining a certain material benefit, in particular, due to the partial replacement of the physical activity, the provision of which requires payment by students (gym services, etc.). For universities, the placement of exercise bikes with a charging function will provide as follows: increase of the level of attractiveness of universities among potential applicants; improving the results of the educational process by improving the students health; obtaining a certain financial benefit in the event that the manufacture of exercise bikes will be carried out in the production units of the university with the subsequent sale of some of these exercise machines to the side. For society as a whole, there are such benefits as energy savings, improving the environment through the production of clean energy, improving the disposal of worn-out bicycles, if they are processed into exercise bikes. The study has shown that the location of exercise bikes in the university area with the function of recharging external devices significantly improves the image of education institutions. At the same time, more than $80 \%$ of the students we interviewed approved the idea of such an innovation. In addition, more than $65 \%$ of respondents expressed a desire to participate in training on these simulators. It was also found that the level of investment costs in the purchase of exercise bikes converted from worn bicycles is about eight times lower than this level in the case of the purchase of new exercise bikes. At the same time, the project of organizing own production of exercise bikes from worn-out bicycles in the presence of the relevant material and technical base in the university is economically feasible.

Keywords: student; health condition; exercise machine; training; energy saving; investment costs. 